\title{
PRINSIP KEHATI-HATIAN (PRECAUTIONARY PRINCIPLE) DALAM PENCEMARAN MINYAK AKIBAT KECELAKAAN KAPAL TANKER DALAM SISTEM HUKUM INDONESIA
}

\author{
Elly Kristiani Purwendah \\ Fakultas Hukum \\ Universitas Wijaya Kusuma Purwokerto \\ Email : elly_kristiani@yahoo.co.id
}

\begin{abstract}
Abstrak
Prinsip kehati-hatian sebagai pengaman dalam kegiatan atau usaha yang berdampak pencemaran bagi lingkungan laut diterapkan dalam sistem hukum nasional melalui peran sentral syahbandar sebagai administrator pelabuhan. prinsip kehati-hatian diterjemahkan melalui bagaimana syahbandar berperan secara administratif mengamankan berbagai hal di awal kegiatan pelayaran laut kapal tanker melalui perijinan dan persyaratan kapal. Syahbandar dalam melaksanakan tugas administratifnya sebagai sebuah perwujudan penerapan prinsip kehati-hatian diwujudkan dalam hal, penyelenggaraan fungsi pelaksanaan pengawasan dan pemenuhan kelaik lautan kapal. Pelaksanaan pengawasan dan pemenuhan fungsi kelaik lautan kapal, sertifikasi keselamatan kapal, pencegahan pencemaran dari kapal dan penetapan status hukum kapal, melaksanakan pemeriksaan managemen keselamatan kapal, melaksanakan pengawasan keselamatan dan keamanan pelayaran terkait dengan kegiatan bongkar muat barang berbahaya dan beracun (B3), pengisian bahan bakar, ketertiban embarkasi dan debarkasi penumpang, pembangunan fasilitas pelabuhan, tertib lalu lintas di perairan pelabuhan dan alur pelayaran, pemanduan kapal serta penerbitan surat persetujuan berlayar. Prinsip kehati-hatian terhadap bahaya di laut dalam hal ini termasuk bahaya pencemaran sudah diantisipasi diawal melalui Kantor Kesyahbandaran dan Otoritas Pelabuhan (KSOP) yang dipimpin oleh seorang Syahbandar dengan didukung oleh struktur organisasi yang meliputi lingkup administrasi dan penegakkan hukum. Bagianbagian organisasi tersebut meliputi lima bidang yaitu, sub bagian tata usaha, seksi status hukum dan sertifikasi kapal, seksi keselamatan berlayar, penjagaan dan patroli, dan seksi lalu lintas dan angkutan laut serta usaha kepelabuhanan.
\end{abstract}

Kata kunci : prinsip kehati-hatian (precautionary principle), pencemaran minyak, syahbandar.

\section{Pendahuluan}

Wilayah laut Indonesia yang mencapai luas 3,11 juta $\mathrm{km}^{2}$ menyebabkan potensi sektor kelautan menjadi tidak ternilai, terutama dari sektor kekayaan alam lautnya. Potensi kekayaan laut menjadi sedemikian penting sebagaimana diprioritaskan oleh Indonesia dalam Konsep green economy dan blue economy yang bermuara pada pembangunan berkelanjutan sebagaimana disampaikan oleh Presiden RI saat memberikan sambutannya dalam Konferensi Rio+20 (United Nations Conference on Suistanable Development) di Rio 
de Jeneiro, Brasil pada tanggal 20-22 Juni 2012.

Lingkungan laut merupakan bagian dari perekonomian suatu negara.Dengan panjang garis pantai sekitar $95.181 \mathrm{~km}$, perairan Indonesia memiliki potensi yang tinggi. Ukuran tersebut merupakan urutan kedua setelah Kanada sebagai Negara yang memiliki garis pantai kedua terpanjang di dunia. Nilai perekonomian dari laut ditaksir mencapai US\$3 triliun - US\$5 triliun atau setara dengan Rp. 36.000 triliun - Rp. 60.000 triliun per tahun. Angka ini belum termasuk potensi lain yang berasal dari kekayaan bioteknologi, wisata bahari maupun pengembangan transportasi laut. Potensi maritim Indonesia yang demikian besar ditangkap sebagai salah satu visi misi unggulan pada pemerintahan presiden Jokowi saat ini. Selain itu, potensi besar ekonomi dan ekologi yang tersimpan sebagai negara maritim, potensi kerusakan alam yang dapat ditimbulkan akibat eksplorasi berlebihan yang dapat mengancam keberlanjutan pembangunan hendaknya juga mendapat perhatian. Untuk itu, saat ini pemerintah tengah mendorong kebijakan ekonomi maritim dengan model ekonomi biru. Pada dasarnya ekonomi biru menggabungkan pengembangan ekonomi dan pelestarian lingkungan.

Dalam kurun waktu 2011-2015 terjadi 4 (empat) pencemaran minyak di laut Cilacap. Pada tahun 2011 ada dua kasus pencemaran pada bulan Juli dan September oleh Kapal Super Tanker TT. Arenza XXVII dan Kapal MT. Medelin Atlas Belawan IMO 8717245, dan pada bulan April 2012 Kapal MV. Indo Baruna V mencemari lingkungan laut Cilacap.
Terakhir di tahun 2015 pada bulan Mei 2015 Kapal tanker MT. Martha Petrol. Tuntutan ganti kerugian pencemaran minyak oleh kapal tanker di laut cilacap dilakukan oleh nelayan kepada PT. Pertamina melalui klaim langsung. Perhitungan ganti kerugian dihitung dalam jumlah kerugian langsung nelayan tidak bisa melaut selama terjadi pencemaran dikalikan jumlah nelayan yang terdaftar sebagai anggota Himpunan Nelayan Seluruh Indonesia (HNSI). Himpunan Nelayan Seluruh Indonesia (HNSI) Kabupaten Cilacap meminta ganti rugi $\mathrm{Rp}$ 40,7 miliar kepada $\mathrm{PT}$ Pertamina RU IV Cilacap akibat kebocoran minyak.

HNSI Cilacap menilai, akibat kejadian itu nelayan sangat dirugikan. Ketua HNSI Cilacap Indon Cahyono menyebutkan, ceceran minyak milik Pertamina itu, selain membuat nelayan tidak bisa melaut, juga merusak jaring dan juga mengotori perahu nelayan. Ganti rugi diajukan karena 13.900 nelayan tidak melaut, kerusakan jaring dan kapal serta perahu yang kotor. Perhitungan kerugian dihitung ribuan nelayan yang tidak bisa melaut selama 15 hari. Penggantian jaring yang rusak adalah untuk 21.200 buah jaring. Sementara itu, untuk ongkos membersihkan kapal dari minyak adalah untuk ribuan kapal duduk, compreng, dan jukung. Tuntutan ganti rugi ini ditujukan ke PT Pertamina RU IV Cilacap. Surat tuntutan ganti rugi tembusannya dikirim ke sejumlah pihak dari Presiden RI, beberapa komisi di DPR, Pertamina Pusat sampai ke Pemkab Cilacap. Tuntutan yang dimintakan adalah membersihkan tumpahan selain menuntut kompensasi, ada tuntutan 
lain, yaitu agar Pertamina membersihkan tumpahan minyak baik di permukaan laut maupun di bawah laut.

Penuntutan ganti kerugian pencemaran laut secara langsung oleh nelayan tanpa peran serta negara tidak sesuai dengan kewajiban negara sebagaimana diatur dalam landasan konstitusional Undang-Undang Dasar 1945, Pasal 33 Ayat 3 yang menyatakan bahwa, "bumi dan air serta kekayaan alam yang terkandung didalamnya dikuasai oleh negara dan dipergunakan untuk sebesar-besarnya kemakmuran rakyat". Pencemaran minyak di Laut Cilacap meninggalkan banyak permasalahan, oleh karenanya penelitian ini berusaha mengkaji permasalahan ganti rugi tumpahan minyak di laut sebagai akibat kecelakaan kapal tanker. Nilai keadilan ganti kerugian pencemaran minyak akibat kecelakaan kapal tanker perlu dikaji secara mendalam mengingat fungsi laut sebagai sumber daya alam yang potensial.

Penelitian ini perlu dilakukan karena penelitian-penelitian terdahulu yang berkaitan dengan ganti kerugian pencemaran minyak akibat kecelakaan kapal tanker belum membahas tentang nilai keadilan dari ganti kerugian tersebut. Penelitian ini dilakukan dengan melakukan analisis terhadap kesesuaian prinsip- prinsip hukum nasional terhadap prinsip hukum dan internasional dan peran institusi-institusi terkait. Kelemahankelemahan dalam praktek dianalisis untuk mendapatkan solusi-solusi yang diperlukan berupa nilai keadilan ganti kerugian. Dalam praktek terjadi kelemahan dalam tuntutan ganti kerugian, hal ini sebagaimana penelitian yang dilakukan oleh Diah Okta Permata W, dkk terhadap kasus pencemaran minyak yang terjadi di Balikpapan, Pemerintah Kota Balikpapan mengajukan gugatan ganti kerugian pencemaran minyak kapal tanker $M T$. Panos $G$ yang berbendera Cyprus ke Pengadilan Negeri Balikpapan. Pihak Pemerintah Kota Balikpapan mengajukan gugatan ganti kerugian sebesar Rp. 6.635.432.804,- (enam milyar enam ratus tiga puluh lima juta empat ratus tiga puluh dua ribu delapan ratus empat rupiah). Nilai tersebut diperhitungkan berdasarkan peringkat kerugian yaitu kerugian pemerintah sebesar Rp. 1.831.905.000,- (satu milyar delapan ratus tiga puluh satu juta sembilan ratus lima ribu rupiah) dan kerugian lingkungan sebesar Rp. 4.803.527.804,- (empat milyar delapan ratus tiga juta lima ratus dua puluh tujuh ribu delapan ratus empat rupiah).

Kelemahan penegakkan hukum di dalam praktek perlu dianalisis menggunakan teori sistem hukum dari Lawrence M. Friedman dan teori peran. Analisis ini perlu dilakukan untuk melihat bagaimana struktur hukum gagal dalam memenuhi nilai ganti kerugian. Kegagalan ini apakah disebabkan karena penerapan prinsip hukum nasional yang tidak sesuai dengan prinsip hukum lingkungan internasional ataukah karena pengaruh budaya hukum yang belum mendukung pemenuhan nilai keadilan. Kemajuan Ilmu Pengetahuan dan Tehnologi serta penghitungan kerugian melalui konsep ekonomi yang menjadi dasar penerapan prinsip-prinsip precautionary principle, strict 
Jurnal Media Komunikasi Pendidikan Pancasila dan Kewarganegaraan Volume 2, Nomor 1 April 2020

liability dan polluter pays principle belum menjadi dasar tuntutan ganti rugi bagi pencemaran laut dalam sistem hukum nasional. Hal ini terbukti dengan keberadaan metode pelacakan jenis minyak melalui metode oil finger print dan pencegahan kerusakan ekologi laut melalui metode bioremidiasi belum menjadi dasar mengajukan penuntutan ganti kerugian pencemaran minyak oleh kapal tanker di Indonesia.

\section{Pembahasan \\ Pengertian Pencemaran Laut}

Pencemaran laut menurut GESAMP (Group of Experts on the Scientific Aspect of Marine Environmental Protection) dipahami sebagai : Pollution means the introduction by man, directly or indirectly, of substances or energy into the marine environment (including estuaries) resulting in such deleterious effect as harm to living resources, hazards to human health, hindrance to marine activities including fishing, impairment of quality for use of sea water and reduction of amenities (IMO, 1993). Polusi berarti pengenaan yang dilakukan oleh manusia, secara langsung atau tidak langsung, dari zat-zat atau energi ke dalam lingkungan laut (termasuk muara) yang menimbulkan efek merusak terhadap sumber daya hidup, berbahaya bagi kesehatan manusia, menghalangi kegiatan-kegiatan kelautan termasuk memancing, penurunan kualitas penggunaan air laut dan berkurangnya kenyamanan (Triatmodjo, 2001).

Pencemaran laut didefinisikan oleh para ahli yang tergabung pada badan-badan di bawah Perserikatan Bangsa-Bangsa sebagai : Introduction by man, directly or indirectly, of substance or energy into the marine environment (including) resulting in such deleterious effects as harm to living resources, hazardous human health, hindrance to marine activities including fishing, impairment quality for use of sea water and reduction of amenities (Kamil Ariadno, 2007). Pengenaan oleh manusia, secara langsung atau tidak langsung, dari zat-zat atau energi ke dalam lingkungan laut (termasuk) yang mengakibatkan efek merusak seperti membahayakan sumber daya hidup, berbahaya bagi kesehatan manusia, mengganggu kegiatan kelautan termasuk memancing, menurunnya kualitas penggunaan air laut dan berkurangnya kenyamanan.

The United States National Oceanic and Atmospheric Administration (NOAA) dalam laporannya dalam konggres mengenai pembuangan limbah disamudra (ocean dumping) mengatakan sebagai, "The unfavourable alteration of the marine environment...thought direct or indirect effect of changes in energy pattern, tradition and distribution, abundance, and quality of organisms". OECD memberikan definisi pencemaran laut merupakan sesuatu yang diakibatkan oleh manusia baik disengaja maupun tidak, yang memberikan efek berupa kerusakan lingkungan maupun ancaman bagi kesehatan umat manusia dan segala sesuatu yang dapat menghambat aktivitas laut termasuk aktivitas perikanan, penurunan kualitas air laut dan 
menganggu kegunaan lain dari lingkungan. Definisi lain, yang diakui secara internasional terdapat dalam Article 1 (4) UNCLOS yang menyebutkan bahwa (Steve Smith, 2005) :

Pollution of the marine or directly, of substances or energy into the marine environment, including estuaries, which results or is likely to result in such deleterious effects as harm to living resources and marine life, hazards to human healts hindrance, to marine activities, including fishing and other legitimate uses of the sea, impairment of quality for uses of the sea, impairment of quality for use of the sea water and reduction of amenitie. Pencemaran laut atau yang secara langsung, dari zat atau energi ke dalam lingkungan laut, termasuk muara, yang menghasilkan atau kemungkinan akan mengakibatkan efek merusak seperti membahayakan sumber daya hidup dan kehidupan laut, berbahaya mengakibatkan gangguan kesehatan manusia, mengganggu kegiatan kelautan, termasuk memancing dan pemanfaatan kelautan lainnya yang sah, penurunan kualitas penggunaan kelautan, penurunan kualitas penggunaan air laut dan berkurangnya kenyamanan.

Dua faktor penting dalam pencemaran laut, yang pertama tindakan yang dilakukan oleh manusia (introduction by men) baik yang disengaja maupun yang tidak disengaja, kedua adalah tindakan manusia tersebut menimbulkan suatu akibat berupa kerusakan pada lingkungan (deleterius effect). Selanjutnya Komar Kantatmadja berpendapat, pencemaran laut adalah telah terjadinya perubahan lingkungan laut yang terjadi sebagai akibat dimasukkannya oleh manusia secara langsung maupun tidak langsung bahan-bahan atau energi ke dalam lingkungan laut yang menghasilkan akibat yang demikian buruknya sehingga merupakan kerugian bagi kekayaan hayati, bahaya terhadap kesehatan manusia, gangguan terhadap kegiatan di laut termasuk perikanan, penggunaan air laut yang wajar, pemburukan daripada kualitas laut dan menurunnya kualitas tempat pemukiman dan rekreasi (Kusumaatmadja, 1977). Komar Kantatmadja berpendapat, pencemaran laut adalah telah terjadinya perubahan lingkungan laut yang terjadi sebagai akibat dimasukkannya oleh manusia secara langsung maupun tidak langsung bahan-bahan atau energi ke dalam lingkungan laut yang menghasilkan akibat yang demikian buruknya sehingga merupakan kerugian bagi kekayaan hayati, bahaya terhadap kesehatan

Prinsip

(Precautionary

Kehati-Hatian

Principle)

Dalam Pencemaran Minyak

Akibat Kecelakaan Kapal Tanker Dalam Sistem Hukum Indonesia

National Assembly Perancis pada tanggal 1 Maret 2005 mengadopsi Piagam Lingkungan Hidup (the Charter for the Environment) tahun 2004 dan mengintegrasikan piagam ini ke dalam Konstitusi Perancis (the Constitution of the French Fifth Republic) (D. Marrani, 2009). Piagam Lingkungan Hidup dijabarkan lebih lanjut dalam Pasal 10 yang berisi tentang berbagai hak dan kewajiban terkait pengelolaan lingkungan. 
Piagam ini menyatakan bahwa setiap orang memiliki hak atas lingkungan hidup yang sehat dan seimbang (Pasal 1), kewajiban kepada setiap orang untuk ikut serta dalam upaya pemeliharaan dan perbaikan lingkungan (Pasal 2), kewajiban untuk menghindari gangguan terhadap lingkungan atau, jika penghindaraan tidak memungkinkan untuk membatasi akibat gangguan tersebut (Pasal 3), mereka yang menyebabkan terjadinya kerusakan lingkungan memikul kewajiban untuk berkontribusi pada perbaikan kerusakan tersebut (Pasal 4), mewajibkan pembuat kebijakan untuk menerapkan asas kehati-hatian, the precautionary principle (Pasal 5), untuk mendukung pembangunan berkelanjutan dengan memadukan perlindungan dan pemanfaatan lingkungan hidup, pembangunan ekonomi serta kemajuan masyarakat (Pasal 6), hak atas informasi lingkungan, serta hak untuk dilibatkan dalam pengambilan keputusan (Pasal 7), pendidikan dan pelatihan terkait lingkungan hidup akan berkontribusi pada pelaksanaan hak dan kewajiban yang dimuat di dalam Piagam Lingkungan (Pasal 8), bahwa riset dan inovasi akan membantu pemeliharaan dan pemanfaatan lingkungan hidup (Pasal 9), piagam lingkungan ini akan berfungsi sebagai acuan bagi penentuan kebijakan Perancis pada level Eropa dan Internasional (Pasal 10).

Menurut Assiddiqie (2009), pengadopsian piagam lingkungan di dalam konstitusi Perancis tidak sekedar penegasan tidak akan ada peraturan perundang-undangan yang bertentangan dengan piagam lingkungan, tetapi merupakan upaya untuk mengukuhkan prinsip-prinsip pengelolaan lingkungan yang merupakan bagian dari hukum serta memasukkan prinsip- prinsip pengelolaan lingkungan yang sudah diakui dalam hukum internasional ke dalam hukum nasional. Pasal 5 Piagam Lingkungan menyatakan bahwa (R. Von Schomberg (eds), 2006) : If the occurrence of damage has the potential affect the environment in a serious and irreversible manner, even though there may be scientific uncertainty, the public authorities should make sure by applying the precautionary principle and within the limits of their attributions, that procedures for evalution of the risks are followed and that provisional and proportionate measures are taken in order to ward off the damage. Jika terjadinya kerusakan memiliki potensi mempengaruhi lingkungan secara serius dan tidak dapat diubah lagi, meskipun mungkin ada ketidakpastian ilmiah, otoritas publik harus memastikannya dengan menerapkan prinsip kehati-hatian dan dalam batas atribusi (pertalian) mereka, bahwa prosedur untuk melakukan evaluasi risiko telah diikuti dan tindakan yang bersifat sementara serta proporsional telah diambil untuk menangkal kerusakan.

Prinsip kehati-hatian ini menekankan pada bagaimana melakukan pencegahan agar tidak terjadi penurunan kualitas lingkungan hidup akibat pencemaran. Lebih jauh lagi, prinsip ini juga mengatur mengenai pencegahan agar tidak terjadi kerusakan lingkungan. Prinsip kehati-hatian digunakan sebagai upaya untuk mengantisipasi dan 
merespon kekawatiran yang timbul sebagai akibat possible harmful efect of technologies (kemungkinan akibat buruk dari penerapan ilmu pengetahuan dan tehnologi) yang mencemarkan atau membahayakan lingkungan hidup (Wibisana, 2008). Prinsip kehati-hatian pertama kali diterapkan dalam kebijakan lingkungan hidup di Jerman pada tahun 1970-an, dan dikenal sebagai vorsorgeprinzip. Tujuan dari vorsorgeprinzip adalah untuk mencegah pencemaran dengan memperkirakan secara seksama potensi timbulnya pencemaran.

Disebutkan pula bahwa prinsip ini merupakan dasar bagi keberlanjutan sumber-sumber ekologi bagi generasi yang datang melalui penggunaan yang hati-hati atas sumber tersebut. Harald Hohmann (1994) menyatakan bahwa vorsorgeprinzip menghasilkan beberapa kewajiban sebagai berikut :

1. kewajiban meminimasi sebabsebab yang mungkin dari kerusakan lingkungan dengan mengambil tindakan-tindakan berdasarkan tehnologi atau ilmu pengetahuan terbaru (state of technologi atau state of science and technology). jika bukti tentang kerusakan tersebut belum terkumpul, adanya kemungkinan saja tentang kerusakan tersebut telah cukup sebagai dasar kewajiban untuk melakukan proses recycle terhadap limbah yang dihasilkan;

2. kewajiban tentang penghindaran (avoidance) dihasilkannya limbah serta pengangkutan/penggunaan bahan-bahan berbahaya sejak proses produksi, serta kewajiban untuk melakukan proses recycle terhadap limbah yang dihasilkan;

3. pelarangan terhadap penurunan kondisi lingkungan saat ini (principle of the status quo preservation), artinya setiap orang didorong untuk tidak melakukan perusakan yang sebenarnya bisa dihindari (avoidable impairments). Status quo preservation juga berarti adanya kewajiban untuk membayar kompensasi terhadap kerusakan yang tidak bisa dihindari;

4. aspek lingkungan secara terus menerus harus diperhatikan dalam setiap perencanaan kebijakan. Hal ini berarti adanya kebutuhan yang lebih besar terhadap diberlakukannya Amdal;

5. pengelolaan lingkungan hidup yang mempertimbangkan aspek ekonomi dari alam, perlindungan dan sumber daya alam;

6. penggunaan sumber daya alam yang secara ekonomi efisien;

7. kewajban untuk membuat pembatasan terhadap penggunaan dan pemasaran bahan-bahan kimia.

Ticker dan Reffensperger menjelaskan bahwa asas kehatihatian memiliki komponenkomponen turunan, baik secara yuridis maupun politis sebagai berikut (Tickner dan Carolyn Reffensperger) :

a. diambilnya langkah kehatihatian (precautionary action) sebelum kepastian ilmiah akan sebab dan akibat berhasil diperoleh;

b. ditetapkannya tujuan yaitu asas 
kehati-hatian mendorong terwujudnya perencanaan yang lebih didasarkan pada tujuan yang telah didefinisikan secara akurat dan bukan tujuan yang didasarkan pada skenario atau perhitungan risiko yang justru seringkali keliru dan bias;

c. penelusuran dan evaluasi alternatif-alternatif kebijakan. Artinya prinsip kehati-hatian lebih menekankan pada pertanyaan bagaimana mengurangi atau menghilangkan bahaya dan mencoba mencari semua alternatif untuk mencapai tujuan tersebut dan bukan didasarkan pada pertanyaan tingkat pencemaran yang seperti apa yang dapat dikatakan aman;

d. keputusan-keputusan yang dibuat dalam rangka penerapan asas kehati- hatian harus bersifat terbuka, demokratik, terinformasikan serta harus menyertakan pihak-pihak yang mungkin terkena dampak dari dikeluarkannya keputusan tersebut;

e. harus terdapat pengalihan beban pembuktian dimana pemrakarsa kegiatan menjadi berkewajiban untuk membuktikan bahwa kegiatannya tidak akan mengakibatkan bahaya bagi kesehatan dan keselamatan manusia dan ekosistem;

f. dikembangkannya metode dan kriteria pengambilan keputusan yang lebih demokratik dan seksama. Asas kehati-hatian masyarakat adanya pertimbangan ilmiah serta bukti/pertimbangan lain (non ilmiah) ketika menghadapi ketidak pastian, sehingga juga

mensyaratkan adanya

pertimbangan yang lebih seksama dan lebih banyak melibatkan partisipasi publik dalam pembuatan kebijakan.

Prinsip kehati-hatian merupakan perwujudan dari pengelolaan lingkungan yang didasakan pada pendekatan antisipatif. Pendekatan ini merupakan pendekatan tahap ketiga dari pendekatan yang dipakai untuk pengelolaan lingkungan (Nicholas Treich, 2001). Prinsip kehati-hatian ditujukan sebagai arahan (guidance) bagi pengambilan keputusan dalam situasi ketidak pastian ilmiah (scientific uncertainty). Pada umumnya asas kehati-hatian dirumuskan dalam pernyataan bahwa apabila terdapat ancaman kerugian yang serius atau tidak bisa dipulihkan (threats of serious or irreversible damage), pengambil keputusan tidak dapat menggunakan kurangnya kepastian atau bukti ilmiah sebagai alasan untuk menunda dilakukannya upaya pencegahan atas ancaman tersebut. Prinsip kehati-hatian berperan besar untuk mengubah arah kebijakan dalam menghadapi bahaya yang serius tetapi masih bersifat tidak pasti. Apabila selama ini para pengambil kebijakan seringkali abai untuk melakukan tindakan pencegahan, dengan prinsip kehati-hatian potensi bahaya tidak lagi diabaikan hanya berdasarkan alasan bahwa bahaya tersebut masih belum jelas dan diliputi oleh ketidakpastian ilmiah (Geistfeld, 2001).

Prinsip kehati-hatian yang dikenal pertama kali di Jerman sebagai sebuah asas pengelolaan lingkungan di dalam hukum lingkungan Jerman 
Jurnal Media Komunikasi Pendidikan Pancasila dan Kewarganegaraan Volume 2, Nomor 1 April 2020

dengan istilah voorsorgeprinzip yang berarti foresight (tinjauan masa depan) dan taking care (berhati-hati). Voorsorgeprinzip mewajibkan negara untuk menghindari terjadinya kerusakan/pencemaran lingkungan dengan melakukan perencanaan secara hati-hati. Prinsip ini juga menjadi pembenaran bagi program pencegahan dan penanggulangan pencemaran secara besar- besaran melalui pemberlakuan tehnologi terbaik (best available technology) untuk meminimalisasi kemungkinan terjadinya pencemaran (A. Jordan dan T. O'Riordan, 1999). Prinsip ini selanjutnya diadopsi dalam berbagai deklarasi atau perjanjian tentang perlindungan lingkungan laut di Eropa. Pencegahan ini dilakukan pada kegiatan dan/atau usaha yang belum diketahui seberapa luas dan besar kerugian dan/atau kerusakannya. Pencegahan dilakukan dengan melakukan langkah nyata, meskipun belum adanya bukti ilmiah mengenai seberapa luas dan besar akibat yang mungkin terjadi. Namun prinsip ini hanya akan berlaku pada perkiraan yang berdampak serius dan kerusakan yang tidak dapat dipulihkan kembali terhadap lingkungan hidup. Prinsip ini berkembang begitu cepat di seluruh belahan bumi sebagai prinsip yang sudah jelas kebenarannya (axiomatic) sebagai prinsip dalam menjaga kelestarian lingkungan hidup (David Freestone dan Ellen Hey, 1996).

Formulasi prinsip kehati-hatian pertama kali muncul dalam The 1984 Bremen Declaration yang diadopsi pada the First International Conference on the Protection of the North Sea. Deklarasi ini menyatakan bahwa : ...damage to the marine environment can be irreversible or remediable only at considerevly expense and over long periods and... therefore, coastal states... must not wait for proof of harmfull effects before taking action...kerusakan pada lingkungan laut bisa jadi tidak dapat diubah atau dapat diperbaiki hanya dengan biaya yang besar dan jangka waktu yang panjang dan... oleh karena itu, negara-negara pantai... tidak boleh menunggu adanya bukti ditemukannya efek yang berbahaya sebelum mengambil tindakan.

Pengakuan prinsip ini dinyatakan kembali dalam The 1987 London Declaration yang diadopsi pada the Second International Conference on the Protection of the North Sea. The 1990 Hague Declaration yang diadopsi pada the Third International Conference on the Protection of the North Sea, The 1995 Esjberg Declaration yang diadopsi pada the Fourth International Conference on the Protection of the North Sea, serta The 2012 Bergen Declaration the Fifth International Conference on the Protection of the North Sea. Berpangkal pada deklarasi-deklarasi tersebut, asas kehati-hatian kemudian diadopsi dalam The 1992 Convention on the Protection of the Marine Environment of the Baltic Sea Area, The 1992 Convention for the Protection of the Marine Environment of the North-East Altantic (OSPAR Convention), The 1995 Barcelona Convention for the Protection of the Marine Environment and the Coastal Region of the Mediterranean (The 1995 Barcelona Convention), The 1996 Izmir Protocol on the Prevention of Pollution of the Mediterranean Sea by Transboundary Movements of 
Jurnal Media Komunikasi Pendidikan Pancasila dan Kewarganegaraan Volume 2, Nomor 1 April 2020

Hazardous Wastes and their Disposal, dan The 2002 Valletta Protocol Concerning Cooperation in Preventing Pollution from Ships and in ases of Emergency. Diluar rezim perlindungan laut, asas kehati-hatian telah dimasukkan di dalam World Charter of Nature (Piagam Lingkungan Dunia) yang diadopsi oleh Majelis Umum PBB pada tahun 1982. Piagam Lingkungan Dunia merumuskan asas kehati-hatian sebagai berikut :

a) activities which are likely to cause irreversible damage to nature shall be avoided;

b) activities which are likely to pose a significant risk to nature shall be preceded by an exhaustive examination; their proponents shall demonstrate that expected benefit outweigh potential damage to nature, and where potential adverse effects are not fully understood activities should not proceed.

Pada Tahun 1992 merupakan tahun yang penting bagi perkembangan asas kehati-hatian. Pada tahun ini, prinsip kehati-hatian diadopsi dalam Maastricht Treaty, Konvensi Helskinsi, United Nations Framework Convention on Climate Change/UNFCCC, Convention on Biological Diversity/CBD dan Deklarasi Rio. Setelah tahun 1992 prinsip kehati-hatian semakin luas diadopsi oleh berbagai perjanjian internasional tentang lingkungan hidup. Berikut ini adalah dokumen internasional sejak tahun 1992 yang memuat asas kehati-hatian :

1. The 1992 Maastricht Treaty menyatakan bahwa kebijakan lingkungan dari komunitas Eropa harus ditujukan untuk mencapai tingkat perlindungan yang tinggi dan harus didasarkan pada asas kehatihatian;

2. The 1992 Helskinki Convention on the Protection and Use of Transboundary Watercourses and International Lake, yang mengakui asas kehati-hatian sebagai asas yang melandasi upaya untuk mencegah, mengendalikan dan mengurangi dampak negatif dari sumber air lintas negara dan danau internasional, disamping juga untuk menjamin konversi dan pemulihan ekosistem; Prinsip kehati-hatian menjadi prinsip yang penting dan diadopsi dalam berbagai kebijakan setelah dituangkan dalam Deklarasi Rio 1992 yang dihasilkan pada The United Nations Conference on Environment and Development (UNCED) di Rio de Jeneiro, Brazil tanggal 3-14 Juni 1992. Prinsip 15 Deklarasi Rio 1992 menyatakan bahwa : In order to protect the environment, the precautionary approach shall be widely appplied by States according to their capabilities. Where there are threats of serious or irreversible damage, lack of full scientific certainty shall not be used as a reason for postponing costeffective measures to prevent environmental degradation" (Freestone, 1994).

Untuk melindungi lingkungan, pendekatan kehati-hatian harus diaplikasikan secara luas oleh Negara-negara sesuai dengan kemampuan mereka. Di mana ada ancaman kerusakan serius atau yang tidak dapat dipulihkan, kurangnya kepastian ilmiah yang penuh tidak boleh digunakan sebagai alasan untuk menunda langkah-langkah yang hemat biaya untuk mencegah 
degradasi lingkungan. Prinsip kehatihatian menunjukkan bahwa kehatihatian perlu dilakukan oleh negara dalam pembuatan kebijakan. Kegiatan yang memiliki kemungkinan untuk menyebabkan dampak yang serius dan tidak dapat dipulihkan inilah yang dalam prinsip ini harus dicegah. Dalam hal ini kurangnya kepastian ilmiah tidaklah dapat dijadikan alasan untuk melakukan penundaan bagi upaya pencegahan.

Laporan dari United Nation Economic and Social Comission for Asia and the Pasific (UNESCAP) menyatakan bahwa, "Believe that, in order to archieve sustainable development policies must be based on the precautionary principle"(Ministerial Meeting in the Environment, 1990, Report of the United Nation Economic and Social Comission for Asia and the Pasific (UN ESCAP). Konsep pencegahan dini ini memang telah diterima dan diterapkan secara luas dalam berbagai aspek kehidupan. Dalam kaitannya dengan prinsip kehati-hatian ini dinyatakan bahwa, "Science does not always provide the insights needed to protect the environment effectively, and that undesirable effect my result if measures are taken only when science does provide such insights" (Ilmu pengetahuan tidak selalu menyediakan wawasan yang diperlukan untuk melindungi lingkungan secara efektif, dan efek yang tidak diinginkan tersebut bisa terjadi jika tindakan yang diambil hanya ketika sains memberikan wawasan tersebut). Dikatakan lebih lanjut bahwa; The essence of precautionary concept, the precautionary principle, is that once a risk has been identified, the lack of scientific proof of cause and effect shall not be used as a reason for not taking action to protect the environment. Inti dari konsep kehatihatian, prinsip kehati-hatian, adalah bahwa sekali risiko telah diidentifikasi, kurangnya bukti ilmiah mengenai sebab dan akibatnya tidak boleh digunakan sebagai alasan untuk tidak mengambil tindakan untuk melindungi lingkungan.

Dari penjelasan tersebut diatas, penerapan prinsip kehati-hatian meliputi beberapa unsur antara lain : 1. once risk has been identified yang berarti bahwa, apabila telah teridentifikasi kerugian yang mungkin timbul; 2. where there are threats of serious or irreversible damage yang berarti

bahwa, apabila ada ancaman yang serius atau ancaman tersebut tidak dapat dipulihkan kembali akibatnya sehingga berdampak selamanya pada lingkungan. Serious dan irreversible damage tidak menentu ukurannya dan harus dilihat kasus perkasus; 3 . lack of scientitic certainty yang berarti bahwa, apabila terdapat kurangnya kemampuan untuk mengukur kemungkinan akan akibat atau dampak yang akan terjadi, sehingga terdapat uncertainty atau ketidak yakinan atas ketidak pastian mengenai besar dan luasnya dampak yang akan terjadi.

Dalam Undang-undang Nomor 23 Tahun 1997 (UUPPLH), tidak ada pengaturan secara spesifik mengenai prinsip kehati-hatian. Pasal 3 UUPPLH mengenai asas, tujuan dan sasaran pengelolaan lingkungan hidup hanya disebutkan asas tangung jawab negara, asas berkelanjutan dan asas manfaat yang bertujuan untuk 
mewujudkan pembangunan berkelanjutan yang berwawasan lingkungan hidup. Dalam UUPPLH prinsip kehati-hatian belum diatur secara jelas. Tidak diaturnya prinsip ini dalam UUPPLH bukan berarti bahwa Indonesia tidak mengenal prinsip kehati-hatian. Sebagaimana dilihat bahwa Indonesia telah melakukan ratifikasi 2 (dua) konvensi yaitu Ratifikasi Konferensi Rio de Jeneiro yang mengandung prinsip kehati-hatian melalui Undangundang Nomor 5 Tahun 1995 tentang Pengesahan United Nations Conventons on Biological Diversity dan Undang-undang Nomor 6 Tahun 1996 tentang Pengesahan United Nations Framework Convention on Climate Change. Ratifikasi yang dilakukan ini menunjukkan bahwa Indonesia menganut prinip kehatihatian dalam perlindungan dan pengelolaan lingkungan hidup.

Kritik terhadap prinsip kehatihatian adalah terdapat perbedaan rumusan prinsip kehati-hatian. Wiener mengelompokkan rumusan asas kehati-hatian ke dalam tiga kelompok yaitu, "uncertainty does not justify inaction", "uncertainty risk justifies action", dan "shifting the burden of proof". Menurut Wiener, rumusan uncertainty does not justify action merupakan versi yang paling lunak, sedangkan shifting the burden of proof merupakan versi yang paling keras dari asas kehati-hatian (D.J. Paustenbach, 2002). Asas kehatihatian sebagaimana tercantum dalam Pasal 5 Piagam Lingkungan Perancis menyatakan bahwa apabila terdapat ancaman kerusakan yang serius dan tidak bisa dipulihkan, maka pejabat publik memiliki kewajiban untuk memastikan, berdasarkan penerapan asas kehati-hatian dan kewenangan yang dimilikinya, bahwa prosedur penilaian risiko (risk assesment) (May, 2005-2006) akan diikuti serta bahwa upaya provisional dan proporsional akan diambil untuk mencegah kerusakan tersebut. Beberapa hal yang perlu diperhatikan adalah :

1. kewajiban melaksanakan asas kehati-hatian ini ditujukan bagi pejabat publik (public authority) dan bukan bagi masyarakat umum;

2. penerapan asas kehati-hatian ini dipicu oleh adanya potensi kerusakan lingkungan yang bersifat serius dan irreversible;

3. penerapan asas kehati-hatian mewajibkan dilakukannya prosedur penilaian risiko (risk assesment) oleh pejabat publik;

4. tindakan kehati-hatian bersifat sementara (provisional);

5. asas kehati-hatian harus ditetapkan bersama-sama dengan asas proporsionalitas.

Godard menganggap bahwa kedinian (earliness) dan asas proporsionalitas merupakan ciri utama dari konsep Perancis atas asas kehati- hatian. Konstitusionalisasi asas kehati-hatian justru berguna untuk menjaga konsep Perancis tentang asas kehati-hatian secara eksesif yang mungkin saja berasal dari hukum Uni Eropa atau perjanjian internasional. Penerapan asas kehatihatian secara proporsional berarti bahwa pada satu sisi tindakan pencegahan haruslah didasarkan pada pertimbangan keuntungan dan biaya (cost and benefits). Pada sisi lain, penerapan asas kehati-hatian secara proporsional harus disesuaikan dengan tingkat ketidakpastian. 
Semakin banyak bukti ilmiah yang menunjukkan adanya bahaya, semakin tinggi besar pula dorongan untuk melakukan pencegahan; sebaliknya ketika bahaya semakin tidak pasti maka keseriusan tindakan pencegahan akan semakin berkurang pula. Semakin banyak bukti ilmiah yang menunjukkan adanya bahaya, semakin tinggi besar pula dorongan untuk melakukan pencegahan; sebaliknya ketika bahaya semakin tidak pasti maka keseriusan tindakan pencegahan akan semakin berkurang pula.

Prinsip kehati-hatian dituangkan secara tersirat dalam Undang-undang Nomor 17 Tahun 2008 tentang Pelayaran (selanjutnya disebut UUP) melalui peran syahbandar sebagai administrator pelabuhan yang melaksanakan tertib administratif dilaut. Dalam Pasal 1 Angka 56 UUP dan Pasal 1 Ayat 18 Peraturan Pemerintah RI Nomor 21 Tahun 2010 tentang Perlindungan Lingkungan Maritim, dikatakan bahwa syahbandar adalah pejabat pemerintah (yang diangkat oleh Menteri) di pelabuhan yang memiliki kewenangan tertinggi untuk melakukan pengawasan terhadap dipenuhinya ketentuan undangundang untuk menjamin keselamatan dan keamanan pelayaran (Elly Kristiani Purwendah dan Agoes Djatmiko, 2015). Keselamatan dan Keamanan pelayaran meliputi keselamatan dan keamanan kemaritiman, sebagaimana ditetapkan oleh UUP perlu dilaksanakan dengan cermat melalui struktur terkait sebagai pemangku kepentingan dalam hal ini diatur tersendiri secara khusus sebagai penjabaran UUP melalui peran Syahbandar, secara tehnis menjadi kepentingan Kantor Kesyahbandaran dan Otoritas Pelabuhan (dulu Administrator pelabuhan dan operasional kapal). Menteri perhubungan mengatur sepenuhnya tentang segala sesuatu yang bertalian dengan penyelenggaraan pelabuhan dan menunjuk seorang pejabat yang memegang tanggung jawab dan pimpinan umum yaitu Administrator Pelabuhan atau Kepala Pelabuhan.

Syahbandar dalam pelaksanaan tugasnya memiliki delapan (8) kewenangan yaitu mengkoordinasikan seluruh kegiatan pemerintahan di pelabuhan, menyimpan surat, dokumen dan warta kapal, menerbitkan surat persetujuan berlayar, melakukan pemeriksaan kecelakaan kapal, menahan kapal atas perintah pengadilan dan melaksanakan sijil awak kapal (Pasal 209, UUP).

Peraturan Menteri Perhubungan Nomor $36 \quad$ Tahun 2012 merekomendasikan bahwa keselamatan dan keamanan pelayaran yang meliputi keselamatan angkutan di perairan, pelabuhan serta perlindungan lingkungan maritim sebagaimana ditetapkan oleh UUP perlu dilaksanakan melalui struktur terkait sebagai pemangku kepentingan melalui peran syahbandar. Menteri mengatur sepenuhnya segala sesuatu yang bertalian dengan penyelenggaraan pelabuhan dan menunjuk seorang pejabat yang memegang tanggung jawab dan pimpinan yaitu Administrator Pelabuhan atau Kepala Pelabuhan ( Peraturan Pemerintah Nomor 1 Tahun 1969, tanggal 18 Januari 1969 tentang Susunan dan Tata Kerja Kepelabuhanan daerah). 
Pentingnya peran syahbandar sebagai administrator pelabuhan terkait pengaman pelayaran di laut baik dari sisi transportasi laut, maupun pencemaran laut. Syahbandar harus bertanggung jawab bahwa pemilik atau operator kapal dalam mengoperasikan kapalnya harus memenuhi persyaratan manajemen keselamatan dan pencegahan pencemaran dari kapal. Kapal yang memenuhi syarat diberi sertifikat manajemen keselamatan dan pencegahan pencemaran dari kapal berupa Dokumen Penyesuaian Manajemen Keselamatan (Document of Compliance/DOC) untuk perusahaan dan Sertifikat Manajemen Keselamatan (Safety Management Certificate/SMC) untuk kapal. Tugas syahbandar sebagai administrator pelabuhan disebutkan dalam Pasal 5 Ayat (1) sampai dengan (7), Pasal 33, Pasal 169 Ayat (1) sampai dengan (6). Dalam Pasal 5 Ayat (1) sampai dengan (7) dikatakan bahwa, batasan pembinaan lingkungan maritim, penguasaan pelayaran pada prinsipnya dikuasai oleh negara dan pembinaannya dilakukan oleh menteri. Pembinaan pelayaran meliputi pengaturan, pengendalian dan pengawasannya ada dalam kewenangan pemerintah daerah. Kemudian dikatakan bahwa, untuk memenuhi perlindungan lingkungan maritim dengan upaya pencegahan dan penanggulangan pencemaran yang bersumber dari kegiatan angkutan di perairan, kepelabuhanan serta keselamatan dan keamanan.

Prinsip kehati-hatian sebagai pengaman dalam kegiatan atau usaha yang berdampak pencemaran bagi lingkungan laut diterapkan dalam sistem hukum nasional melalui peran sentral syahbandar sebagai administrator pelabuhan. prinsip kehati-hatian diterjemahkan melalui bagaimana syahbandar berperan secara administratif mengamankan berbagai hal di awal kegiatan pelayaran laut kapal tanker melalui perijinan dan persyaratan kapal. Syahbandar dalam melaksanakan tugas administratifnya sebagai sebuah perwujudan penerapan prinsip kehatihatian diwujudkan dalam hal, penyelenggaraan fungsi pelaksanaan pengawasan dan pemenuhan kelaik lautan kapal. Pelaksanaan pengawasan dan pemenuhan fungsi kelaik lautan kapal, sertifikasi keselamatan kapal, pencegahan pencemaran dari kapal dan penetapan status hukum kapal, melaksanakan pemeriksaan managemen keselamatan kapal, melaksanakan pengawasan keselamatan dan keamanan pelayaran terkait dengan kegiatan bongkar muat barang berbahaya dan beracun (B3), pengisian bahan bakar, ketertiban embarkasi dan debarkasi penumpang, pembangunan fasilitas pelabuhan, tertib lalu lintas di perairan pelabuhan dan alur pelayaran, pemanduan kapal serta penerbitan surat persetujuan berlayar. Prinsip kehati-hatian terhadap bahaya di laut dalam hal ini termasuk bahaya pencemaran sudah diantisipasi diawal melalui Kantor Kesyahbandaran dan Otoritas Pelabuhan (KSOP) yang dipimpin oleh seorang Syahbandar dengan didukung oleh struktur organisasi yang meliputi lingkup administrasi dan penegakkan hukum. Bagianbagian organisasi tersebut meliputi lima bidang yaitu, sub bagian tata usaha, seksi status hukum dan sertifikasi kapal, seksi keselamatan 
berlayar, penjagaan dan patroli, dan seksi lalu lintas dan angkutan laut serta usaha kepelabuhanan.

Penerapan prinsip kehati-hatian dalam peran syahbandar/KSOP sebagai administrator tertuang dalam struktur organisasi, Bidang Status Hukum dan Sertifikasi kapal yang bertugas melaksanakan pemeriksaan pengujian dan sertifikat kelaiklautan, keselamatan kapal, pencegahan pencemaran dari kapal dan manajemen keselamatan kapal serta status hukum kapal. Seksi Sertifikasi Kapal memiliki peran fungsi yang salah satunya adalah melaksanakan pemeriksaan peralatan pencegahan pencemaran dan pembersihan tanki serta verifikasi manajemen keselamatan dan pencegahan pencemaran dari kapal. Selain itu sertifikasi kapal memiliki tugas sampai kepada pembersihan kapal serta perlindungan ganti rugi pencemaran.

Bidang organisasi lain di KSOP terkait dengan fungsi dalam penerapan prinsip kehati-hatian adalah bidang pencegahan dan penanggulangan Pencemaran yaitu, Bidang Keselamatan Berlayar, Penjagaan dan Patroli yang mempunyai tugas melaksanakan pengawasan tertib lalu lintas di perairan pelabuhan dan alur pelayaran, pemanduan dan penundaan kapal, penerbitan surat persetujuan berlayar, kegiatan alih muat di perairan pelabuhan, salvage dan pekerjaan bawah air, bongkar muat barang berbahaya, barang khusus, pengisian bahan bakar, limbah B3, ketertiban embarkasi dan debarkasi penumpang, pembangunan fasilitas pelabuhan, pengerukan dan reklamasi, pelaksanaan bantuan pencarian dan penyelamatan (Search and Rescue/SAR), pengendalian dan koordinasi penanggulangan pencemaran serta pemadaman kebakaran di pelabuhan, pelaksanaan perlindungan lingkungan maritim, pelaksanaan pemeriksaan dan verifikasi sistem keamanan kapal dan fasilitas pelabuhan (International Ship dan Port Facility Security Code/SPS Code), pemeriksaan pendahulan pada kecelakaan kapal, penegakkan hukum di bidang keselamatan dan keamanan pelayaran serta pelaksanaan koordinasi kegiatan pemerintahan di pelabuhan yang terkait dengan pelaksanaan pengawasan dan penegakkan hukum di bidang keselamatan dan keamanan pelayaran.

Syahbandar memiliki otorisasi pelabuhan termasuk di dalamnya adalah memberi ijin untuk kapal tanker masuk ke wilayah teritorinya, hal ini vital sekali mengingat rentannya sebuah kapal tanker akan kecelakaan kapal yang berakibat pencemaran minyak. oleh karenanya prinsip kehati-hatian yang diterapkan dalam sistem hukum nasional mengenai peran syahbandar dalam pemberian ijin kapal tanker memasuki otoritas wilayahnya harus mengingat pada, penerbitan surat persetujuan berlayar (port clearance) yang merupakan suatu proses pengawasan yang dilakukan oleh syahbandar terhadap kapal yang akan berlayar meninggalkan pelabuhan untuk memastikan bahwa kapal, awak kapal dan muatannya secara teknis administratif telah memenuhi persyaratan keselamatan dan keamanan pelayaran serta perlindungan lingkungan maritim. Surat Persetujuan Berlayar (port 
clearance) merupakan dokumen negara yang dikeluarkan oleh Syahbandar kepada setiap kapal yang akan berlayar meninggalkan pelabuhan setelah kapal memenuhi kelaik lautan kapal dan kewajiban lainnya. Syahbandar sebagai pejabat pemerintah di pelabuhan yang diangkat oleh Menteri memiliki kewenangan tertingi untuk menjalankan dan melakukan pengawasan terhadap dipenuhinya peraturan perundang-undangan untuk menjamin keselamatan dan keamanan pelayaran.

Pejabat pemeriksa kelaik lautan kapal adalah pejabat kesyahbandaran yang ditunjuk dan telah memiliki kualifikasi dan kompetensi di bidang kesyahbandaran. Kelaik lautan disini dimaksud sebagai sebuah keadaan yang memenuhi persyaratan keselamatan kapal, pencegahan pencemaran perairan dari kapal, pengawakan, garis muat, pemuatan, kesejahteraan awak kapal dan kesehatan penumpang, status hukum kapal, manajemen keselamatan dan pencegahan pencemaran dari kapal dan manajemen keamanan kapal untuk berlayar di perairan tertentu (Bab I. Ketentuan Umum, PM Perhubungan KM 01 tahun 2010). Secara administratif, peran syahbandar mengamankan transportasi laut dalam hal ini transportasi kapal tanker untuk tidak melakukan pencemaran. Pemenuhan prinsip kehati-hatian dilaksanakan melalui UUP, PP No. 1 Tahun 1969 tentang Susunan dan Tata Kerja Kepelabuhan dan daerah, PP Nomor 21 Tahun 2010 tentang Perlindungan Lingkungan Maritim, Peraturan Menteri Perhubungan Nomor KM. 01 tahun 2010 tentang Tatacara
Penerbitan Surat Persetujuan Berlayar (port clearance) dan Peraturan Menteri Perhubungan Nomor 36 Tahun 2012 tentang Organisasi dan Tata Kerja Kantor Kesyahbandaran dan Otoritas Pelabuhan.

Meskipun secara preventif administratif prinsip kehati-hatian sudah diterapkan melalui peran syahbandar sebagai administrator pelabuhan, ada hal yang perlu dievaluatif sebagai sebuah kontrol mekanisme preventif administratif yaitu peran negara selaku administrator yang memiliki otorisasi teritorial terkait dengan ijin kapal tanker yang bisa masuk ke wilayahnya dalam hal ini Bidang Status Hukum Kapal. Status hukum kapal terkait dengan Bendera Kapal yang diartikan sebagai sebuah penundukkan diri kapal terhadap entitas legitimasi kedaulatan negara dari kapal tersebut. Bendera kapal, dalam kasus yang diteliti sangat berkaitan dengan penerapan prinsip kehati-hatian (sekaligus secara tidak terpisah juga berkaitan dengan prinsip pencemar membayar. Dari tiga (3) kapal tanker yang mengalami kecelakaan di Laut Cilacap, dua (2) kapal tanker berbendera Malta dan satu (1) kapal berbendera Indonesia.

Kapal berbendara Indonesia tidak memiliki asuransi CLC sehingga pihak PT. Pertamina RU. IV Cilacap tidak mau memberikan ganti kerugian kepada pihak nelayan. Perbedaan bendera kapal dan pemberian ganti kerugian terhadap korban pencemaran, dalam kasus yang diteliti mencirikan bahwa prinsip kehati-hatian yang seharusnya dilaksanakan secara administratif oleh administrator pelabuhan terkait 
Jurnal Media Komunikasi Pendidikan Pancasila dan Kewarganegaraan

Volume 2, Nomor 1 April 2020

kelaik lautan dan status hukum kapal belum diterapkan dengan baik dan cenderung masih bersifat tebang pilih, bagi kapal tanker berbendera Indonesia prinsip kehati- hatian tidak diterapkan, kapal tanker MT. Martha Petrol tidak memiliki asuransi dan tidak bisa membayar klaim kerugian akibat pencemaran minyak.

\section{Kesimpulan}

Inti dari konsep kehati-hatian, prinsip kehati-hatian, adalah bahwa sekali risiko telah diidentifikasi, kurangnya bukti ilmiah mengenai sebab dan akibatnya tidak boleh digunakan sebagai alasan untuk tidak mengambil tindakan untuk melindungi lingkungan. Penerapan prinsip kehati-hatian meliputi beberapa unsur antara lain : 1. once risk has been identified yang berarti bahwa, apabila telah teridentifikasi kerugian yang mungkin timbul; 2 . where there are threats of serious or irreversible damage yang berarti bahwa, apabila ada ancaman yang serius atau ancaman tersebut tidak dapat dipulihkan kembali akibatnya sehingga berdampak selamanya pada lingkungan. Serious dan irreversible damage tidak menentu ukurannya dan harus dilihat kasus perkasus; 3. lack of scientitic certainty yang berarti bahwa, apabila terdapat kurangnya kemampuan untuk mengukur kemungkinan akan akibat atau dampak yang akan terjadi, sehingga terdapat uncertainty atau ketidak yakinan atas ketidak pastian mengenai besar dan luasnya dampak yang akan terjadi. Dalam Undangundang Nomor 23 Tahun 1997 (UUPPLH), tidak ada pengaturan secara spesifik mengenai prinsip kehati-hatian.

\section{Daftar Pustaka}

A. Jordan dan T. O'Riordan, 1999, The Precautionary Principle in Contemporary Environmental Policy and Politics dalam C. Raffensperger dan J. Tickner (eds), 1999, Protecting Public Health and the Environment: Implementing the Precautionary Principle, Island Press, Washington DC.

Asshiddiqie, J., 2009, Green Constitution: Nuansa Hijau Undang-undang dasar Negara Republik Indonesia Tahun 1945, Rajawali Press, Jakarta.

D. Marrani, 2009, Human Rights and Environmental Protection: The Pressure of the Carter for the Environment on the French Administrative Courts, Sustainable Development Law and Policy, Vol. 10.

David Freestone dan Ellen Hey, 1996, Origins and Development of the Precautionary Principle, dalam The Precautionary Principle and International Law, The Challenge of Implementation, Hague, Kluwer Law international.

David Freestone, 1994, The Road from Rio: International Environmental Law after the Earth Summit, Journal of Environmental Law 6.

Elly Kristiani Purwendah dan Agoes Djatmiko, 2015, Peran Syahbandar dalam Penegakkan Hukum Pencemaran Minyak di Laut oleh Kapal Tanker, Perspektif, Vol. XX, No. 1 Tahun 2015, Edisi Januari.

Harald Hohmann, 1994, Precautionary Legal Duties and Principles of Modern 
Jurnal Media Komunikasi Pendidikan Pancasila dan Kewarganegaraan

Volume 2, Nomor 1 April 2020

International Law: The precautionary principle: International Environmental Law between Exploitation and Protection, Graham\&Trotman, London.

IMO, 1993, Impact of Oil and Related Chemicals on the Marine Environment, IMO/FAO/UNESCO/WMO/IAEA/ UN/UNEP Joint Group of Expert on the Scientific Aspect of Marine Pollution (GESAMP), London.

J.B. Wiener, Precaution in a Multirisk World, dalam D.J. Paustenbach, 2002, Human and Ecological Risk Assessment: Theory and Practise, John Wiley and Sons, New York.

J.R. May, 2005-2006, Constituting Fundamental Environmental Rights Worldwide, Pace Environmental Law Review, Vol. 23.

Joel Tickner dan Carolyn Reffensperger, The precautionary principle in Action: A Handbook, first edition, http://www.biotech_info.net/hand book.pdf.

John Baylish, Steve Smith, 2005, The Globalization of World Politics (3rd ed), Oxford University Press, Oxford.

M. Geistfeld, 2001, Implementing the Precautionary Principle, Environmental Law Reporter, Vol. 31.

M.R.A.G. Wibisana, 2008, Law and Economic Analysis of the Precautionary Principle, Disertasi Doktor, Maastricht University, Maastricht.

Mangku, D. G. S. (2010). Pelanggaran terhadap Hak Kekebalan Diplomatik (Studi
Kasus Penyadapan Kedutaan Besar Republik Indonesia (KBRI) di Yangon Myanmar berdasarkan Konvensi Wina 1961). Perspektif, 15(3).

Mangku, D. G. S. (2011). Peluang dan Tantangan ASEAN Dalam Penyelesaian Sengketa Kuil Preah Vihear Di Perbatasan Kamboja dan Thailand. Pandecta: Research Law Journal, 6(2).

Mangku, D. G. S. (2012). Suatu Kajian Umum tentang Penyelesaian Sengketa Internasional Termasuk di Dalam Tubuh ASEAN. Perspektif, 17(3).

Mangku, D. G. S. (2013). Kasus Pelanggaran Ham Etnis Rohingya: Dalam Perspektif ASEAN. Media Komunikasi FIS, 12(2).

Mangku, D. G. S. (2017). The Efforts of Republica Democratica de Timor-Leste (Timor Leste) to be a member of Association of Southeast Asian Nations (ASEAN) and take an active role in maintaining and creating the stability of security in Southeast Asia. Southeast Asia Journal of Contemporary Business, Economics and Law, 13(4), 18-24.

Mangku, D. G. S. (2018). Kepemilikan Wilayah Enclave Oecussi Berdasarkan Prinsip Uti Possidetis Juris. Jurnal Advokasi, 8(2), 150-164.

Mangku, D. G. S. (2018). Legal Implementation On Land Border Management Between Indonesia And Papua New Guinea According to Stephen B. Jones Theory. Veteran Law Review, 1(1), 72-86.

Mangku, D. G. S., \& Itasari, E. R. (2015). Travel Warning in International

Law 
Jurnal Media Komunikasi Pendidikan Pancasila dan Kewarganegaraan

Volume 2, Nomor 1 April 2020

Perspective. International Journal of Business, Economics and Law, 6(4).

Mangku, D. G. S., \& Radiasta, I. K. (2019). Tanggung Jawab Negara terhadap Penembakan Pesawat MH17 berdasarkan Hukum Internasional. Pandecta: Research Law Journal, 14(1), 25-33.

Mangku, D. G. S., Triatmodjo, M., \& Purwanto, H. (2018). Pengelolaan Perbatasan Darat Antara Indonesia Dan Timor Leste Di Wilayah Enclave Oecussi (Doctoral dissertation, Universitas Gadjah Mada).

Marsudi Triatmodjo, 2001, Pengembangan Pengaturan Hukum dan Kelembagaan Pencemaraan Laut dari darat di Kawasan Asia Tenggara, dalam Hukum dan Lingkungan Hidup di Indonesia, 75 Tahun Prof. $R$. Koesnadi Harjasoemantri, SH, $M L$.

Melda Kamil Ariadno, 2007, Hukum Internasional Hukum yang Hidup, Diadit Media, Jakarta.

Ministerial Meeting in the Environment, 1990, Report of the United Nation Economic and Social Comission for Asia and the Pasific (UN ESCAP).

Mochtar Kusumaatmadja, 1977, Pencemaran Laut dan Pengaturan Hukumnya, Universitas Padjajaran, Bandung.

Nicholas Treich, 2001, What is the Economic Meaning of the Precautionary Principle?, The Geneva Papers on Risk and Insurance, Vo. 26, No. 3, 2001.

O. Godard, The Precautionary Principle and Catastrophism on Tenterhooks: Lessons from a Constitutional Reform in France, dalam E. Fisher, J. Jones dan R. Von Schomberg (eds), 2006, Implementing the Precautionary Principle: Perspective and Prospects, Edward Edgard, Cheltenham, UK.

Purwanto, H., \& Mangku, D. G. (2016). Legal Instrument of the Republic of Indonesia on Border Management Using the Perspective of Archipelagic State. International Journal of Business, Economics and Law, 11(4).

Purwendah, E., Mangku, D., \& Periani, A. (2019, May). Dispute Settlements of Oil Spills in the Sea Towards Sea Environment Pollution. In First International Conference on Progressive Civil Society (ICONPROCS 2019). Atlantis Press.

Sakti, L. S., Mangku, D. G. S., \& Yuliartini, N. P. R. (2020). Tanggung Jawab Negara Terhadap Pencemaran Lingkungan Laut Akibat Tumpahan Minyak Di Laut Perbatasan Indonesia Dengan Singapura Menurut Hukum Laut Internasional. Jurnal Komunitas Yustisia, 2(3), 131-140.

Setiawati, N., Mangku, D. G. S., \& Yuliartini, N. P. R. (2020). Penyelesaian Sengketa Kepulauan Dalam Perspektif Hukum Internasional (Studi Kasus Sengketa Perebutan Pulau Dokdo antara Jepang-Korea Selatan). Jurnal Komunitas Yustisia, 2(2), 241-250.

Setiawati, N., Mangku, D. G. S., SH, L. M., Yuliartini, N. P. R., \& SH, M. (2019). Penyelesaian Sengketa Kepulauan Dalam Perspektif Hukum Internasional (Studi Kasus Sengketa Perebutan Pulau Dokdo 
Jurnal Media Komunikasi Pendidikan Pancasila dan Kewarganegaraan

Volume 2, Nomor 1 April 2020

$\begin{array}{lr}\text { antara } & \text { Jepang-Korea } \\ \text { Selatan). Jurnal Komunitas } & \text { Kustisia, 2(1). }\end{array}$

Widayanti, I. G. A. S., Mangku, D. G. S., SH, L. M., Yuliartini, N. P. R., \& SH, M. (2019). Penggunaan Tentara Anak Dalam Konflik Bersenjata Ditinjau Dari Perspektif Hukum Humaniter (Studi Kasus: Konflik Bersenjata Di Sri Lanka). Jurnal Komunitas Yustisia, 2(1).

Wiratmaja, I. G. N. A., Mangku, D. G. S., \& Yuliartini, N. P. R. (2020). Penyelesaian Sengketa Maritime Boundary Delimitation Di Laut Karibia Dan Samudera
Pasifik Antara Costa Rica Dan Nicaragua Melalui Mahkamah Internasional. Jurnal Komunitas Yustisia, 2(1), 60-69.

Yuliartini, N. P. R., \& Mangku, D. G. S. (2019). Tindakan Genosida terhadap Etnis Rohingya dalam Perspektif Hukum Pidana Internasional. Majalah Ilmiah Cakrawala Hukum, 21(1), 41-49.

Yuliartini, N. P. R., \& Mangku, D. G. S. (2019). Tindakan Genosida terhadap Etnis Rohingya dalam Perspektif Hukum Pidana Internasional. Majalah Ilmiah Cakrawala Hukum, 21(1), 41-49. 